\title{
Judicial Activism in Brazil's Constitutional Court: Studies in the Recognition of Brazilian Indigenous Tenure Rights
}

\author{
Anna Lucia Berardinelli* \\ Lawyer at Berardinelli and Meirelles Law Firm, Brazil
}

\begin{abstract}
Small part of entire Brazil's national territory has already been demarcated as indigenous land. Facts reveal that the Natives were killed because of land issues, indicating that land issues and tenure rights are the epicenter of the problem. This article focuses on the cardinal point of Brazilian legal debates: keeping indigenous people's tenure over the land they have been occupying immemorially. The analysis explores normative aspects on constitutional and legal protection over Brazilian indigenous rights and further scrutinizes the relevant case law that was settled before the Brazil's Constitutional Court.
\end{abstract}

Keywords: Brazil, Indigenous, Constitution, Court.

\section{INTRODUCTION}

Like many countries, such as Indonesia, Australia and United States of America, Brazil struggles with the issue of indigenous people's rights over their immemorial land. More than a thousand years before the Portuguese first arrived in Brazil in the 14th century, native people already immemorially inhabited its land. Those who lived there that called by the Portuguese the single denomination of "Indians", despite the fact that there were a huge mosaic of different tribes and ethnic groups ${ }^{1}$ that made livelihood from hunting, collecting, and simple and semi nomadic agricultural methods. ${ }^{2}$

As centuries went through, it became very clear that the denomination they had been given was extremely poor in meaning. Once inside the indigenous cultural spectrum, there was a vast and rich linguistic, religious and cultural diversity. In fact, those tribes were so foreign to one another that occasionally bloody wars erupted between them. ${ }^{3}$

Although there were innumerous differences between tribes, some common practices could be observed among the great majority of them. ${ }^{4}$ Many of those practices ended up having strong influence in shaping Brazilian identity, such as some

\footnotetext{
* Correspondence: annalucia@bmcalaw.com.br

${ }^{1}$ Leandro Narloch, Guia Politicamente Incorreto da História do Brasil (São Paulo, BR: Leya, 2010), 317.

2 Pedro Ignácio Schmitz, Migrantes da amazônia: a tradição tupiguarani (Porto Alegre, BR: Unisinos, 2005), 30-35.

3 Darcy Ribeiro, O Povo Brasileiro (São Paulo, BR: Companhia de Bolso, 2003), 15.

4 Itamaraty, Brazilian International Relations Department. "A Cultura dos Povos Indígenas",http:// dc.itamaraty.gov.br.
} 
culinary $^{5}$ and hygiene knowledge, as well as the assimilation of many indigenous words by Portuguese Language ${ }^{6}$ and also assimilation of some animist tales to national folklore. ${ }^{7}$

Brazilian indigenous people unconsciously contributed to consolidating colonization process. By sharing their knowledge over land and climate with the Portuguese, they helped those foreigners to conquer territory and also demarcate new frontiers.

Even though a considerable number of laws have been approved under the purpose of protecting the indigenous people, native population was dramatically reduced, between the 16th and 20th centuries, killed not only by tenure fights, but also infectious diseases brought by European colonists.

It is possible to conclude that everything was a sad aftermath of the lack of admiration Portuguese conquers had towards those indigenous cultures. And by not admiring it, inevitably, they did not respect it. They considered local culture behind its time, without any refinement, and especially against Christianity's sense of morality, ${ }^{8}$ which was so important for Portuguese society of that time. Indigenous people were looked upon barbarian, and naïve. Above all, assimilating European culture was then scientifically considered something superior, and therefore desirable.

The result was tragic. Tribes that did not surrender peacefully to this forced acculturation process (as it did happen to many tribes) were brutally destroyed by Portuguese troops, which were much more superior militarily.

With the rise of Age of Enlightenment in the 17th century, the major view towards indigenous people gave place little by little to a new and romanticized image of native tribes. They were seen as pure and capable of living in much more harmony with the environment. ${ }^{9}$

Looking at the history of Brazil on the seventeenth century, it is possible to state that the Age of Enlightenment gained much force in literature and other art forms. Important artists and intellectuals began portraying Brazilian indigenous people. This romanticized image was not able to stop the slavery and systematic killing of indigenous people by Portugal colonizers.

5 Gilberto Freyre, Casa-grande \& senzala: formação da família brasileira sob o regime da economia patriarchal (São Paulo, BR: Global, 2006), 163-165.

6 Museu do İndio, "Influência da cultura indígena em nossa vida vai de nomes a medicina”, http:// prodoc.museudoindio.gov.br.

7 Maria do Carmo Pereira Coelho, As Narrações da Cultura Indigena da Amazônia - Tese de Doutorado. (São Paulo, BR: PUC-SP, 2003), 145-162.

8 Ricardo Ventura Santos; Flowers, Nancy e Coimbra Jr., and Carlos E. A. eds., Demografia, Epidemias e Organização Social: os Xavánte de Pimentel Barbosa (Etéñitépa), Mato Grosso. (Rio de Janeiro: FIOCRUZ, 2005), 69-71.

9 Afrânio Biscardi \& Frederico Almeida Rocha, eds.,"O Mecenato Artístico de D. Pedro II e o Projeto Imperial”, http://www.dezenovevinte.net/ensino_artistico/mecenato_dpedro.htm 
Natives were never really considered equals. Many of the laws approved, from that times to this day, treat the natives in contradictory ways. By trying to protect natives, Brazil's Government declared their incapacity and by doing so, made them dependent on Government's charity.

There has been a lot of discussion about what would be the effective strategy to protect native tribes. Many efforts were made during the 1980s helped the growth of population which had been decreasing systematically. Participation and involvement of international organizations such as United Nations (UN), Organization of American States (OAS) and International Labor Organization (ILO) as well as the international agreements made by those organizations played a major role in improving their condition. Despite all efforts done, in this 21 st century, the situation is still alarming.

When looking towards a better future, the present is still a violent reality, especially when concerning fights over land. According to official data, ${ }^{10} 12.54 \%$ of the entire national territory has already been demarcated as indigenous land". Most of the villages are located in the Amazon rainforest. Two-thirds of the indigenous population lives in these Amazonian reserves and the remaining one-third is compressed in small remaining territory, spread around the entire country. Between the years 2003 and 2011, more than 500 natives were killed, because of land issues. In the following year, the violence grew by $237 \% .{ }^{11}$ This data indicates that land issues and tenure rights are the epicenter of the problem, because land is a powerful force and root of fundamental values for every culture.

Recognizing the importance of this matter, and pushed by social movements over land rights, in 1988 Constitution of the Federative Republic of Brazil (hereinafter, Brazil's Constitution) declared that all people must be equal towards law without any kind of distinction. By doing so, the Brazilian Constitution recognized multiculturalism and expressively protected many indigenous rights, among them tenure over their immemorial land, and the preservation of their culture in their natural habitat.

\section{APPROACH}

This essay focuses on the cardinal point of Brazilian legal debates: keeping indigenous people's tenure over the land they have been occupying immemorially. Here, the case under analysis will be a trial, decided by the Brazil's Constitutional Court - STF (Supreme Federal Court), in the year of 2008. The review is going to be done from the perspective of a contemporary debate among today's legal scholars: Constitutional Court's lack of democratic legitimacy, considering Constitutional Judges are commonly not elected democratically, and therefore limit their ability to

\footnotetext{
${ }^{10}$ FUNAI,http://www.funai.gov.br/index.php/indios-no-brasil/terras-indigenas.

${ }^{11}$ Dermi Azevedo, “Cimi: Novo genocídio ameaça povos indígenas do país”,http://www.cartamaior.com.br.
} 
broaden hermeneutics and introduce innovative interpretations of the Constitution when faced a challenge of making a controversial decision.

In the following pages, STF's decision in the legal case "Raposa Serra do Sol" (State of Roraima vs. Federal Union and Indigenous People's Council, 2008) will be analyzed from the point of view of rights protected, and the decision's consistency with 1988's Constitution. This essay's goal is to investigate this controversial decision's democratic legitimacy in the context where the dichotomy judicialization of politics versus judicial activism is growing over the issue of global justice.

\section{ANALYSIS}

\subsection{Normative Content - Brazilian Indigenous Law}

Through Act 6001/1973, Brazilian law has protected indigenous rights since the 1970s. Unfortunately, this is a law diploma of its time, which means that it still brings the old vision of indigenous people who are in need of being introduced to and assimilated into western civilization. This law describes Government charity and care towards the natives while adopting some progressive western approach and phagocytosis.

Of course that this outdated point of view is no longer in accordance to Brazil's Constitution of 1988, which brings the latest concerns in relation to human rights and global justice. But when a new constitution is enacted, is impossible for one country to change all its legal system at once. Therefore, Brazil's Constitution, as did Indonesia's, provided transitional provisions.

That leads to the fact that Brazilian indigenous protective system is a complex and imperfect one, formed by six constitutional articles, ${ }^{12}$ one outdated law (Act 6001/1973) and few other ordinances (Ordinance 22/1991; Ordinance 1775/1996). That means a lot of work to legal interpreters because many controversial legal concepts, such as "indigenous community" and "indigenous land", need to be interpreted by Constitutional Court to define precise legal meaning.

\section{2. "Raposa Serra do Sol" Jurisprudence}

A legal case "Raposa Serra do Sol" - State of Roraima vs. Federal Union and Indigenous People's Council, $2008^{13}$ is a good example of how Brazil's Constitution is apllied and interpreted in this issue. It was an emblematic trial that brought against each other various different segments of Brazilian society. At one side there

12 Brazil's Constitution, Arts.22, XIV;129, V; 231; 232; Transicional Provisions, Arts.14 § 1º 67.

13 STF - Brazil`s Constitutional Court. Demarcação de Terras Indígenas: Raposa Serra do Sol. Brasília,http://www.stf.jus.br/arquivo/informativo/documento/informativo725.htm 
were unhappy rice farmers, the State of Roraima, part of the army, groups of landless people, all together against Federal ordinance 534/2005 that fixed a huge part of Roraima's territory (Raposa Serra do Sol area) as indigenous land. At the other side, Brazil's national government, Catholic Church, Indigenous Rights Council and Environmental Council asserted that natives immemorially occupied controversial land, and that Brazil's Constitution had secured indigenous tenure over it.

After many violent conflicts, a Roraima's Senator sued the national government, stating that land demarcation at "Raposa Serra do Sol" area was done disregarding 1988's Constitution and pleaded the invalidity of Ordinance 534/2005. He argued that, in essence, the Ordinance in question possessed vices: a) people and entities affected by the controversy hadn't all been heard; b) the anthropological report on the area under discussion would have been signed by just one professional; c) disastrous consequences would negatively affect both the State of Roraima in the commercial, economic and social aspects, and the country in terms of compromises in national security and sovereignty; d) the land demarcation pattern, done without intervals between indigenous villages, almost transferred the power of State of Roraima over a huge part of its territory towards National Government, and therefore would have created an imbalance of the Federation; e) the ordinance violates the principle of reasonableness by privileging the tutelage of natives against the private sector.

In their defense, national government and Indigenous Council contended that: a) Constitutional Articles 231 and 232 predicted the guardianship of the natives and favor them in land tenure over the indigenous land; b) indigenous lands are national government's property, as stated by the Constitution; c) the state of Roraima was created after 1988 when 1988's Constitution had already defined that indigenous land belonged to National Government, therefore no territory subtraction, or lack of equity concerning the ordinance could be sustained by states.

In the end of a long and polemic trial, The Constitutional Court - STF favored indigenous people's theses, backing National Government's pleas. Regarding indigenous tenure over borderland and potential sovereignty issues, the Court ruled that the Constitution did not make any exception and that natives have always opposed the attempts of foreign invasions. It was also added that this decision was indeed a excellent reason to increase border police presence in the region, not only to protect borders and sovereignty, but also indigenous people themselves.

Also concerning potential damages to landowners, it was held that the term "originários", ${ }^{14}$ contained in Article 231 of the Constitution, reflects the oldest and most powerful right concerning land to prevail on any non-natives' public deeds or tenure titles. It has been argued that private rice farmers, who were occupying indigenous lands since 1992, would not have a legitimate tenure, because the previous tenure was actually fraudulent. In addition to that, the presence of extensive rice farming

\footnotetext{
${ }^{14}$ In free translation, originating.
} 
was turning the soil in this area an unfertile one, what could represent an immense damage to natives' activities and also degrades environmental resources, necessary for the welfare of all natives.

Crowning the decision, it was stressed that Brazil's Constitution would as well recognize indigenato, ${ }^{15}$ which is a legal institution that keeps tradition dating back to colonial times and that is more powerful than any other vulgar tenure, contained in civil law. By recognizing so, Brazil is following an international tendency in dealing with the indigenous issue and global justice concern, such as concerns from Australia, New Zealand, Canada and the USA.

Finally, the proportionality principle was emphasized to assure the dignity of indigenous life conditions to their present life and future generations. Regarding the continuous format of the indigenous demarcation, without any interval between villages, it was stressed that the will of Constitution was to be generous to native people. As said by the Court, Articles 231 and 232 have a clearly fraternal purpose, bringing natives a new kind of equality, namely, civil and moral minorities' equality. It is clear, therefore, an option to adopt a mechanism of affirmative action (or positive discrimination).

\subsection{Affirmative Action or Positive Discrimination-A New Kind of Equality to Minorities}

To take affirmative action (or positive discrimination) means to promote the opportunities of defined minority groups within a society to give them equal access to what the majority of population already has. It is often instituted by Government to ensure that certain designated "minority groups" have the equal rights. It also helps to compensate for past discrimination, persecution or exploitation by the ruling class of a certain culture ${ }^{16}$ and to address existing discrimination.

The affirmative action or positive discrimination doctrine was introduced to deal with the finding that it is insufficient to treat individuals equally, in a generic way. It was found that to provide true equality it is necessary to treat each individual or group individually towards law, considering their uniqueness. This means to give certain groups special protection, making them able to face their own vulnerability.

15 The legal institution of indigenato is the recognition by Brazilian government of immemorial indigenous land title, in order to assure natives have their social organization, customs, languages, beliefs and traditions, as well as tenure to the lands they traditionally occupy.

${ }^{16}$ Thomas Sowell, Affirmative Action Around the World: An Empirical Study (New Haven: Yale University Press, 2004). 
After Brazil adopted International Convention on the Elimination of All Forms of Racial Discrimination, ${ }^{17}$ many legal scholars in the nation, such as Boaventura de Souza Santos, are developing theses about this subject, trying influence Courts and Judges, and by doing so, compensate many injustices in Brazilian society, mostly regarding slavery and injustices towards indigenous people. Bellow Santos's teaching in a translation:

“... We have the right to be equal when our difference makes us inferior; and have the right to be different when our equality mischaracterizes us. Hence the need for a kind of equality, that recognizes differences, but also the right to be different without producing, or reproducing inequalities". ${ }^{18}$

North American experience ${ }^{19}$ proves that affirmative actions are effective in providing greater equality, what means that these actions are relevant in implementing right to equality. Brazil's Legislative has already implemented some affirmative actions, especially concerning injustices related to slavery. But towards indigenous people not much has been done yet. Therefore, the emergent adoption of affirmative action to promote better equality in opportunities to natives, especially through compensatory measures. And considering the Legislative lack of action, it is very important that the Judiciary assume its role in ensuring the Constitution.

\subsection{Innovative jurisprudence: Judicialization of politics or judicial activism?}

Despite the fact that Brazil's Constitutional Court gave a brilliant and innovative decision to the case, it was subject of strong criticism, regarding the broadening interpretation given, in order to set new, and needed, regulation for the indigenous tenure issue. In recent years, $\mathrm{STF}^{20}$ has played an active role in Brazil's institutional life by deciding innumerous polemic social and political issues, always innovating in its jurisprudence.

This is a phenomenon known as judicialization of politics, which means that some social or political issues are being decided by the Judiciary, and not by conventional and democratically elected institutions, such as Legislative and Executive. But this is not a Brazilian singularity: in many different parts of the world, in dif-

\footnotetext{
17 Article 1 of the International Convention on the Elimination of All Forms of Racial Discrimination defines racial discrimination as: “... any distinction, exclusion, restriction or preference based on race, color, descent or national or ethnic origin which has the purpose or effect of nullifying or impairing the recognition, enjoyment or exercise, on an equal footing of human rights and fundamental freedoms."

18 Boaventura de Souza Santos, "Por uma concepção multicultural de direitos humanos". 1997, Revista Crítica de Ciências Sociais, 48, 11-32.,"(São Paulo, BR: PUC-SP, 2003), Cadernos de Pesquisa, v. 35, n. 124, p. 429-461.

${ }^{19}$ Flávia Piovesan, Açõesfirmativas da Perspectiva dos Direitos Humanos (São Paulo: PUC-SP, 2005),Cadernos de Pesquisa, v. 35, n. 124, p. 53. http://egov.ufsc.br/portal/sites/default/files/ anexos / 15390-15391-1-PB.pdf

${ }^{20}$ Brazil`s Constitutional Court, http://www.stf.jus.br.
} 
ferent times of history, Constitutional and Supreme Courts stood out as protagonists in political issues of wider significance, helping implementing public policies. ${ }^{21}$

But what would be the phenomenon's causes? The first one to be pointed out is recent democratization. That was clearly Brazil's case, especially considering the political environment after the end of dictatorship, and promulgation of 1988's Constitution. During dictatorship period, Brazil's Judiciary was more a technical institution, but after the end of it, the judiciary system, mainly STF, could really take its place as a political power, enforcing the Constitution.

Analytical Constitutions, being very detailed ones, could be pointed as the second cause to the phenomenon, as stating about numerous matters, which were previously left to ordinary legislation. This kind of more detailed Constitution was a worldwide trend, brought by Portugal's (1976) and Spain's (1978) Constitutions. Brazil also followed this trend in 1988. The issue with this pattern is that every matter stated by the Constitution, is a potential new law case before the Constitutional Court that ends up deciding many social and political issues.

Therefore, it is possible to conclude that judicialization and the major role played by constitutional courts are more a natural consequence of democratizations than an evil to be avoided. But this could turn into an undemocratic way of acting, unbalancing political powers. This phenomenon is known as judicial activism and considered as undesirable.

The origins of judicial activism date back to American jurisprudence. According to Luis Roberto Barroso, a Brazilian legal scholar and a judge at the Brazilian Constitutional Court, ${ }^{22}$ judicial activism is "an attitude, choosing a specific and proactive way of interpreting the Constitution, expanding its meaning and scope. Usually it settles in Legislative retraction situations, when a certain detachment between the political class and civil society, when denial of social incoming demands can be observed."23 Still learning from his teachings, what distinguishes judicial activism is a pattern in broadening the application of the Constitution and enforcement hypotheses, forcing Executive to take action in implementing public policies.

In "Raposa Serra do Sol" trial, the Court established eighteen new premises concerning indigenous land and indigenous tenure. ${ }^{24}$ All premises were based on Brazil's Constitution, Acts and Ordinances related to the subject. But as aimed bellow,

21 Luis Roberto Barroso ,"Judicialização, Ativismo Judicial e Legitimidade Democratica”,http:// www.direitofranca.br/direitonovo/FKCEimagens/file/ArtigoBarroso_para_Selecao.pdf, page 2.

22 Professor of Constitutional Law, PhD and Associate Professor - State University of Rio de Janeiro (UERJ). Master Yale Law School. Author of Contemporary Course of Constitutional Law and Judicial Review in Brazilian Law, among others. Judge at STF - Brazil`s Constitutional Court.

${ }^{23}$ Luis Roberto Barroso, 17.

${ }^{24}$ STF - Brazil`s Constitutional Court. 
the Court progressed towards a much more detailed jurisprudence, truly innovating on the subject:

1) Use of soil and its riches, rivers and lakes located in indigenous lands can be suppressed by the National Government, based on national interest; ${ }^{25}$

2) Indigenous tenure does not cover the exploitation of water resources, which always depends on legislative authorization; ${ }^{26}$

3) Indigenous tenure does not cover research and mining, which always depends on legislative authorization; ${ }^{27}$

4) Indigenous tenure does not include mining, or sparking mining, which depends on Small-scale Mining Association's authorization; ${ }^{28}$

5) National defense policy prevails over indigenous tenure, and the installation of military bases, military posts and other military interventions, can be implemented by the National Defense Council without any prior consultation towards communities or FUNAI; ${ }^{29}$

6) As a matter of duty, military forces and Federal Law enforcement shall occupy indigenous land, and their presence will be guaranteed regardless of whether any consultation took place with communities or FUNAI; ${ }^{30}$

7) Indigenous tenure does not prevent the installation of public facilities, especially concerning health and education, but also communication networks, roads and transportation networks by the National Government; 31

8) Indigenous tenure over environmentally protected areas restricts entry, transit and residence, as well as hunting, fishing and the extraction plant (restricted to periods, seasons and conditions fixed by law; ${ }^{32}$

9) Chico Mendes Institute for Biodiversity Conservation in charge of environmentally protected area (also affected by indigenous tenure) is only allowed to give suggestions concerning indigenous communities, traditions and mores after consulting FUNAI; ${ }^{33}$

\footnotetext{
${ }^{25}$ Brazil’s Constitution, Art. 231; Act 6001/73, Art. 62. 9314/96.

${ }^{26}$ All of Brazil's Constitution, Arts. 49, XVI; 20, XI, 176; 231, § 3; Ordinance 227/67, and Act

27 Brazil`s Constitution, Art. 231, § 3.

28 Article 231, § 7, c / c 174 §§ 3 and 4 of Brazil's Constitution. Act 6567/78; Act 7805/89;

29 Brazil`s Indigenous Council, http://www.funai.gov.br and Brazil`s Constitution, Art. 171, § 1, I; 142; 22, CF XXXVIII; Ordinance 5484 / 05.

30 Act $6001 / 73$, Art. 34.

${ }^{31}$ Brazil's Constitution, Arts. 220; 224; 88; 21, XII, d); 22, XI; 177;178. CF 220/224/88), (Articles 21, XII, d), XX all of Brazil's Constitution.

${ }^{32}$ Act 7643/87; Act 7679/88; Ordinance 221/67 and Act 11380/06, and Brazil`s Constitution, Art. $231, \S 2$.

33 Act $11.516 / 07$.
} 
10) Non-natives are allowed to visit environmentally protected area (that is also indigenous land) at times and conditions stipulated by the park administration; ${ }^{34}$

11) Concerning indigenous land, which is not designated as environmentally protected, non-natives' entry, transit, or residence is subject to the conditions set out by FUNAI; ${ }^{35}$

12) Non-natives' entry, transit, or residence is free of any charge from indigenous community; ${ }^{36}$

13) Use of roads, public facilities, power transmission lines or other equipment and facilities placed in service to the public is free of any charge from indigenous community; ${ }^{37}$

14) Indigenous lands shall not be subject to lease, selling or any other act or business that could restrict the full and direct exercise of indigenous tenure; ${ }^{38}$

15) Hunting, fishing and gathering fruit as well as mining and agricultural activities are strictly prohibited on indigenous lands by any non-natives; ${ }^{39}$

16) Indigenous tenure, and all assets that come from it, is free of any charge from the Government, and enjoy full tax exemption, thus shall not be subjected to the collection of any taxes or fees; 40

17) Indigenous land shall not be expanded;

18) Indigenous tenure shall prevail over any other tenure, under any circumstances, and indigenous land is inalienable and unavailable, and cannot be object of sale, donation or any business of any kind. ${ }^{41}$

From the above statements, it is possible to state that even though the STF has already done a great job, pushing jurisprudence further, there is still a long way ahead to effectively protect indigenous people. Despite the activism sparkle in this decision, Brazil's law is still behind international standards.

Analyzing STF decision, it is possible to conclude that the judicialization phenomenon, but not judicial activism, is present in the "Raposa Serra do Sol" trial. This case represents a natural consequence of the constitutional pattern adopted. Even the most innovative aspects of this trial were based on the law. There is no trace of deliberate maneuver to turn it into a political decision. Added to that, de-

\footnotetext{
34 Act $11.516 / 07$.

35 Act 5371/67; Ordinance 3156/99.

36 Brazil`s Constitution, Art. 150.

37 Ibid.

38 Ibid., Art. 231, § 4.

39 Ibid., Art. 231, § 2.

40 Act 6.001/73Art. 60; Act 9.393/96.

41 Brazil`s Constitution, Art. 231, § 4.
} 
spite all polemic concerning the trial, the Court had to decide the law case, as a matter of duty, once indigenous land is a matter to be ruled under the 1988's Constitution. As explained above, this is a main aspect of this phenomenon. But above all, the decision was in accordance with a major thought in the country, and therefore a democratic and legitimate one.

\section{CONCLUDING REMARKS}

In Brazil's legal system, indigenous land is demarcated by FUNAI, the Indigenous Council, that is responsible for protecting interests of the indigenous people (land, culture, and way of living). This pattern differs from the one adopted by the United States of America, where the Federal Government signed treaties with native tribes to reserve land under tribal and individual native's ownership. Brazilian's indigenous lands, as already stated above, even if already demarcated, are inalienable National Government's assets, over which indigenous people have lifetime tenure towards Brazil's Constitution. ${ }^{42}$

Disputes concerning indigenous land dating from colonial times always have been cause to controversy, violence, human rights violations and corruption. ${ }^{43}$ Nowadays, the areas located outside Amazon rain forest are the main stage where the most violent conflicts take place because of high population density. This was exactly the case of "Raposa Serra do Sol" area, located on the State of Roraima. Indigenous people usually face a lot of opposition from farmers and mining corporations, particularly in areas where agribusiness, mining companies and industries use their enormous political power and economic influence to gain access to indigenous land, as happened in Roraima.

Despite all difficulties, the solution to indigenous lands issue has important implications, not only for the survival of those peoples, but also for forests conservation. Natives are known to deal with environment in a way to protect its reproductive capacities.

It seems that there is still a long way in achieving the goals as expected in international agreements that have been adopted by Brazil. According to Millennium Ecosystem Assessment, a major scientific publication on environment issues, although more comprehensive scientific studies are necessary to confirm this, it seems that indigenous people's occupation in their immemorial land and their continuation of traditional way of living as be an effective tool for the preservation of forests as wildlife

42 Joênia Batista de Carvalho, a casa é um asilo inviolável. Series Via dos Sabers n. 3 (Brasília: MEC/ Enesco, 2006), 85-101.

43 Liana Laurence, "Presidente da Funai sai em meio a conflitos indígenas e mudanças nas regras de demarcação,"http://memoria.ebc.com.br/agenciabrasil 
sanctuaries. ${ }^{44}$ Brazil is one of the world champions in deforestation, and suffers from numerous other threats that endanger biodiversity and ecosystems, such as pollution and global warming. In this sense, the natives' role, settled in their own land and keeping their traditional way of life, is an essential one. The entire world should learn from indigenous communities as they are considered examples of sustainable forest management.

Indigenous people fate, in Brazil, is still uncertain, and many fights are to be expected ahead. Disputes concerning their lands continuously multiply. Even with all the advances and legal protection, even with all the communities' political awareness, their joint mobilization, and even with the support of a significant portion of Brazil's non-native population and international organizations, many communities still face deaths, abuse, and violence. There is still a long way to ensure indigenous people get their land for their survival in a dignified and independent way. It would be ideal that they do not require government's guardianship. Historically, they were understood as incapable of living without such guardianship. Yet, the government has been unable to provide indigenous people with the rights that have been constitutionally guaranteed.

As a matter of fact, many changes will be brought by the creation of regional councils to address economic aspects of challenges by increasing business opportunities. Proposed changes will inevitably lead to land issues. As discussed above, land plays a major role in keeping traditional ways of life. Keeping traditional ways of life helps to protect the environment. It is a two-way road. Unfortunately, many of today's economic activities, such as mining, agricultural activities, and huge factories harm land. As a consequence, they can harm traditional communities in its existence and dignity.

Learning from Brazil's experience, is important to keep in mind when facing strong economic power and trying to provide global justice. Sometimes legislative and executive actions may not be enough. A strong judiciary system, mainly a strong constitutional court, is needed that is mature enough to ensure the constitution protection for those who are most vulnerable against all threats.

44 Core Writing Team, Ecosystems and Human Well-being: A Report of the Millennium Ecosystem Assessment(Washington DC: Island Press,2005). 


\section{BIBLIOGRAPHY}

\section{Books}

Carvalho, Joênia Batista de. A casa é um asilo inviolável. Series Via dos Sabers n. 3. Brasilia: MEC/Enesco, 2006.

Coelho, Maria do Carmo Pereira. As Narrações da Cultura Indígena da Amazônia Tese de Doutorado. São Paulo, BR: PUC-SP, 2003.

Core Writing Team. Ecosystems and Human Well-being: A Report of the Millennium Ecosystem Assessment. Washington DC: Island Press, 2005.

Freyre, Gilberto. Casa-grande \& senzala: formação da família brasileira sob o regime da economia patriarchal. São Paulo, BR: Global, 2006.

Narloch, Leandro. Guia Politicamente Incorreto da História do Brasil. São Paulo, BR: Leya, 2010.

Ribeiro, Darcy. O Povo Brasileiro. São Paulo, BR: Companhia de Bolso, 2003.

Santos, Ricardo Ventura; Flowers, Nancy e Coimbra Jr., and Carlos E. A., eds. Demografia, Epidemias e Organização Social: os Xavánte de Pimentel Barbosa (Etéñitépa), Mato Grosso. Rio de Janeiro: FIOCRUZ, 2005.

Schmitz, Pedro Ignácio. Migrantes da amazônia: a tradição tupiguarani. Porto Alegre, BR: Unisinos, 2005.

Sowell, Thomas. Affirmative Action Around the World: An Empirical Study. New Haven: Yale University Press, 2004.

\section{Journals}

Piovesan, Flávia. "Ações Afirmativas da Perspectiva dos Direitos Humanos" (São Paulo: PUC-SP, 2005), Cadernos de Pesquisa, v. 35, n. 124, p. 53. http:// egov.ufsc.br/portal/sites / default/files / anexos / 15390-15391-1-PB.pdf

Santos, Boaventura de Souza. (1997), "Por uma concepção multicultural de direitos humanos “, Revista Crítica de Ciências Sociais, 48, 11-32.

Paulo, BR: PUC-SP, (2003), Cadernos de Pesquisa, v. 35, n. 124. 


\section{Legal Document}

Act 5.371/67. Establishes the creation of Indigenous Council, FUNAI.

Act 6.001/73. Indigenous Law.

Act 6.567/78. Establishes rules for mining.

Act 7.643/87. Establishes rules for fishing.

Act 7.805/89. Establishes rules for mining.

Act 9.393/96. Establishes rules for rural property.

Act 11.516 / 07. Establishes the creation of the Chico Mendes Institute for Biodiversity Conservation - Instituto Chico Mendes.

Constitution of the Federative Republic of Brazil

International Convention on the Elimination of All Forms of Racial Discrimination, United Nations, Treaty Series, vol. 660, p. 195.

\section{Internet}

Azevedo, Dermi. “Cimi: Novo genocídio ameaça povos indígenas do paîs,” http:// www.cartamaior.com.br

Barroso, Luis Roberto. “Judicialização, Ativismo Judicial e Legitimidade Democratica,"http:/ / www.direitofranca.br/direitonovo/FKCEimagens / file/ ArtigoBarroso_para_Selecao.pdf

Biscardi, Afrânio and Frederico Almeida Rocha, eds., "O Mecenato Artístico de D. Pedro II e o Projeto Imperial",

http://www.dezenovevinte.net/ensino_artistico/mecenato_dpedro.htm

FUNAI, http://www.funai.gov.br/index.php/indios-no-brasil/terras-indigenas

Itamaraty, Brazilian International Relations Department. "A Cultura dos Povos Indigenas," http:/ / dc.itamaraty.gov.br

Laurence, Liana. Presidente da Funai sai em meio a conflitos indígenas e mudanças nas regras de demarcação", http://memoria.ebc.com.br/agenciabrasil 
Udayana Journal of Law and Culture

Vol. 01 No.1, January 2017

Museu do İndio. "Influência da cultura indígena em nossa vida vai de nomes a medicina" ,http://prodoc.museudoindio.gov.brSTF - Brazil`s Constitutional Court, "Demarcação de Terras Indígenas: Raposa Serra do Sol",http:// www.stf.jus.br/arquivo/informativo/documento/informativo725.htm 